\title{
CORRECTIVE FEEDBACK RECAST USES IN STUDENTS' UPTAKE IN PAST FORM EXPRESSIONS
}

\author{
Theresia Arianti and Dery Rovino* \\ Program Studi Pendidikan Bahasa Inggris, STKIP Media Nusantara Citra \\ Received on 16 October 2019 / Approved on 25 October 2019
}

\begin{abstract}
Research studies have shown that recasts are one of the types of corrective feedback frequently used by teachers in second language teaching. However, little is known about the effectiveness of recasts in second language teaching within Indonesian context since most Interactional Approach studies conducted with Indonesian context focus on corrective feedback in general, not particularly on recasts. Moreover, most of these studies do not include past forms as the language feature being studied. The current study investigated the use of recasts in yielding students' uptake in past forms (Verb type II). 5 participants were involved in the study. Pairing with the examiner, each participant engaged in a jigsaw-task activity where they received recasts. The recast episodes produced by each participant were analyzed and coded into some categories, which were "repair", "needs-repair : acknowledgement", "needs-repair : modified", "needs-repair : unmodified", and "no uptake". The result showed that the uptake which was mostly produced by participants was "needs-repair : acknowledgement". This finding contradicts the one in the previous study which showed that the uptake that was most frequently produced by the participants was "repair". The finding of this study is expected to trigger further studies to examine students' perception towards recasts that leads to the ineffectiveness of it.
\end{abstract}

Keywords: corrective feedback; recast; past forms; speaking skills

\begin{abstract}
ABSTRAK
Penelitian menunjukkan bahwa recasts merupakan salah satu jenis umpan balik yang paling sering digunakan dalam pembelajaran bahasa asing. Namun demikian, hanya sedikit informasi yang tersedia mengenai penggunaan recasts dalam konteks pembelajaran bahasa asing di Indonesia. Sebagian besar penelitian yang memakai Interactional Approach di Indonesia berfokus pada umpan balik secara umum, bukan secara khusus pada recasts. Selain itu, sebagian besar penelitian tersebut tidak mengambil past forms sebagai elemen bahasa yang diteliti. Pada penelitian ini, past forms menjadi elemen bahasa yang digunakan untuk meneliti kegunaan recasts dalam proses pembelajaran bahasa asing. Sebanyak 5 mahasiswa melakukan kegiatan jigsaw-task dimana mereka menerima recasts dari peneliti ketika ditemukan kesalahan past forms dalam kalimat yang mereka buat. Setiap episode recasts dari tiap peserta dikodekan dan diberi kategori sebagai berikut: "repair", "needs-repair : acknowledgment", "needs-repair: modified", "needs-repair: unmodified" dan "no uptake". Data menunjukkan bahwa sebagian besar uptake yang dihasilkan oleh peserta masuk dalam kategori "needs-repair : acknowledgment". Hasil ini berbanding terbalik dengan hasil penelitian sebelumnya yang menunjukkan bahwa sebagian besar uptake yang dihasilkan oleh peserta studi dalam penelitian tersebut masuk dalam kategori "repair". Hasil penelitian ini diharapkan dapat menjadi landasan penelitian-penelitian berikutnya mengenai bagaimana pelajar mempersepsikan recasts.
\end{abstract}

Kata Kunci: umpan balik; recast; ujaran masa lampau; kemampuan berbicara

*Author(s) Correspondence:

E-mail: theresia.arianti@stkipmnc.ac.id,dery.rovino@stkipmnc.ac.id 


\section{INTRODUCTION}

The use of corrective feedback in Second Language (L2) learning has long been studied by many researchers, especially the ones interested in the field of Interaction Approach. As stated by Lightbown and Spada (2013, p. 140), corrective feedback consists of explicit correction, recasts, clarification requests, metalinguistic feedback, elicitation, and repetition. Amongst these, recasts seem to be the most interesting type of feedback for many researchers, because of their effectiveness as well as their ambiguity. According to Lightbown and Spada (2013, p. $140)$, recasts can be defined as the teacher's reformulation of the learner's incorrect utterance without explicit information about the error.

The effectiveness of recasts is seen as the result of the positive and negative evidence that they promote. Positive evidence refers to the information about how a particular linguistic form is used in the L2, while negative evidence refers to the information about what is incorrect in the L2. However, the implicitness of recasts is seen as a disadvantage for learners since they often fail to get the corrective focus of recasts. Accoding to Lyster (1998a), in Nicholas, Lightbown \& Spada (2001, p. 719), the ambiguity of recasts causes learners to perceive them as confirmation of meaning instead of feedback.

This leads to the statement of the problem for the current study which is how learners perceive recasts. A research question is then established, that is "which uptakes do learners produce upon receiving recasts?". This study aims to examine the uptake produced by learners upon receiving recasts.

There is a various number of research studies that have been conducted to examine the use of recasts. However, a vast majority of them focus on students' perceptions towards recasts instead of the uptake produced by students. One of them is the one conducted by Mackey, Gass and MacDonough (2000) which examined students' perceptions of recasts and negotiation. This is the gap that will be filled by the current study which focuses on students' uptake.

The use of corrective feedback in Indonesian context has also long been examined. However, most of them do not focus on recasts. One of those studies is the one conducted by Maolida (2013) which analyzed the use of oral feedback in an ESL study in Indonesia. The study analyzed oral positive and corrective feedback in English teaching without the use of recasts as the main focus. A similar study was conducted by Solikhah (2016) which examined the types of corrective feedback used by lecturers in teaching speaking. Recasts were not the main foci of these researches. This gap will be filled by the current study since it focuses only on recasts.

Despite the fact that most interactional feedback studies in Indonesia do not specifically examine recasts, there are some that have recasts as their main foci. It is then assumed that the effective use of recasts has been known by many teachers in Indonesia. However, it is found that despite teachers' awareness of the importance of recast, the tendency to continue or change the topic of discussion without providing sufficient time for students to produce uptake occurs in the language teaching in Indonesia. As stated by Langit-Dursin (2016), teachers tend not to give the sufficient amount of time for students to give their uptake. As a result, many students do not have the opportunity to produce their uptake. This is another gap that the current study attempts to fill since it will give a sufficient amount of time for students to give uptake during the treatment.

Besides the gaps mentioned above, past form is also an important aspect that differentiates the current study from the ones conducted before. Most studies examining recasts with Indonesian context do not include past form as their focus of research. Pronunciation is one that is widely used to scrutinize the use of recasts in language teaching. One instance for this is the research conducted by Haryanto (2015) that focused on the use of corrective feedback on learners' pronunciation. Compared to the previous

\footnotetext{
*Author(s) Correspondence:

E-mail: theresia.arianti@stkipmnc.ac.id,dery.rovino@stkipmnc.ac.id
} 
studies mentioned above, it is evident that the current study will bring a new insight into the type of uptake produced by learners who receive recasts in past-form.

Learners' perception and uptake toward recasts have frequently been examined in previous studies. These studies mostly involve university students or school students as the participants. As stated by Egi (2010, p. 7), his study involved students of Japanese language studying at either universities or language schools located in North America. Similarly, Carpenter, Jeon, MacGregor and Mackey (2006, p. 221) mentioned that their study involved students from universities and community colleges in the United States as the participants. Moreover, Panova and Lyster (2002, p. 579) also stated that the participants of their study consisted of ESL students in a school in Canada. It can be said that most studies examining recasts involve students who do not study at English Education as the participants. This is one gap that will be fulfilled by this study since it will involve English Education students as the participants.

\section{LITERATURE REVIEW}

\section{Recast}

The use of recasts in L2 learning has long been studied by many researchers. Recasts are generally defined as the teacher's reformulation of the student's incorrect utterance with the correct form. As stated by Long (1996), in Leeman (2003, p. 38), recasts are the reformulation of learners' incorrect utterance without changing the meaning. This is in line with the definition of recasts in other studies. According to Nicholas, Lightbown and Spada (2001, p. 732), recasts are defined as the repetition of learners' incorrect utterance by replacing the error with the correct form, without giving any change in the meaning. Moreover, Lyster and Ranta (1997), in Rassaei (2014, p. 418), explained that recasts refer to the reformulation of learners' incorrect utterance with the correction of the error. The definitions of recasts from previous studies show that recasts are categorized as implicit feedback since they do not contain the explicit information about the learners' error. Besides their implicitness which is commonly seen as a disadvantage for learners, recasts are also believed to be effective for L2 development.

The effectiveness of recasts is the result of the negative and positive evidence that they promote. A study examining negative and positive evidence in recasts was conducted by Leeman (2003). This study tried to figure out the effectiveness of positive and negative evidence contained in recasts. According to Leeman (2003, p. 38), negative evidence refers to the information about what is impossible in the L2, while positive evidence refers to the information about what kind of utterances are possible in the L2. The result showed that the benefit of recasts is gained from their positive evidence, not the negative evidence. As stated by Leeman (2003, p. 56), the negative evidence group in the study did not outperform the control group, showing that negative evidence is less likely to enhance L2 development. In addition, Leeman (2003, p, 56) stated that the enhanced salience of positive evidence group in the study outperformed the control group on all measures in the posttests. These findings showed that the positive evidence contained in recasts is the one that enhances L2 development.

Despite of their effectiveness, it is undeniable that recasts might also render a number of disadvantages to the learners. This ineffectiveness of recasts was examined by Rassaei (2014). This study focused on two types of corrective feedback which were recasts and scaffolding. While recasts are categorized as implicit feedback, scaffolding is the combination between implicit and explicit feedback. In scaffolding, the type of feedback given is adjusted to the learners' developmental level. Participants in this study were divided into recasts group, scaffolding group and control group. The analysis of the pretests and posttests showed that both recasts

\footnotetext{
*Author(s) Correspondence:

E-mail: theresia.arianti@stkipmnc.ac.id,dery.rovino@stkipmnc.ac.id
} 
and scaffolding groups outperformed the control group, with scaffolding group significantly outperformed the recasts group. This revealed that scaffolding is more beneficial than recasts for L2 development.

There are several possibilities why recasts are not as effective as scaffolding. The most crucial factor is the implicitness of recasts which leads them to be ambiguous. On the other hand, as stated by Rassaei (2014, p. 427), scaffolding leads learners to be aware of their error. It is because scaffolding contains more explicit information about the error. This might be a strong reason why scaffolding is more beneficial than recasts for enhancing L2 development.

Previous studies showed that recasts, which are defined as the teacher's reformulation of the learners' incorrect utterance with the correct form, bring an advantage and a disadvantage for learners. Recasts are advantageous since they contain positive evidence; however, they are also ambiguous for several learners. This case is highly related to how learners perceive recasts.

\section{Perception}

It is believed that learners perceive recasts differently. Some of them perceive recasts as feedback, while some others have different perceptions of recasts. According to Lyster (1998b) in Carpenter et al. (2006, p. 212), learners often perceive the corrective component of recasts as confirmation of meaning. Similarly, Lyster (1998a) in Nicholas, Lightbown \& Spada, 2001 (p. 719) also stated that the ambiguity of recasts leads learners to perceive them as confirmation of meaning instead of corrective feedback. This shows that learners often perceive recasts in different ways.

A study that examined learners' perceptions of recasts was conducted by Mackey, Gass and McDonough (2000). This study analyzed learners' perceptions of interactional feedback which were recasts and negotiation. According to Mackey, Gass and McDonough (2000, p. 490), the result showed that learners are mostly inaccurate in perceiving morphosyntactic feedback. Mackey, Gass and McDonough (2000, p. 493) explained that in this study, recasts were mostly used to give morphosyntactic feedback. It is the clear that there is a correlation between learners' perceptions of recasts and their misperception of the morphosyntactic feedback.

A similar study was conducted by Carpenter, Jeon, MacGregor and Mackey (2006). This study examined learners' interpretation of recasts, including the nonlinguistic cues that might affect it. Participants in this study were divided into two groups: one group was shown a video of recasts without the incorrect utterance that preceded them, while another group was shown a video of recasts with the incorrect utterance that preceded them. Carpenter et al. (2006, p. 226) stated that when participants heard the incorrect utterance preceding the recasts, they were more likely to interpret the recasts correctly. In addition, Carpenter et al. (2006, p. 228) also mentioned that participants did not pay attention to nonlinguistic cues when interpreting recasts. These findings showed that linguistic context in which recasts occur is highly important for allowing learners perceive recasts correctly.

Previous studies showed that learners often perceive recasts incorrectly because they fail to get the corrective component of recasts. It is likely that recasts are perceived as confirmation of meaning instead of feedback. It is believed that learners' misperception of recasts hinders them to give uptake.

\section{Uptake}

The relationship between learners' perceptions of recasts and uptake has been frequently examined in previous research. According to Lyster (1998, in Rassaei, 2014, p. 419), uptake refers to the response given by

\footnotetext{
*Author(s) Correspondence:

E-mail: theresia.arianti@stkipmnc.ac.id,dery.rovino@stkipmnc.ac.id
} 
learners towards corrective feedback. Moreover, Lyster and Ranta (1997, in Panova \& Lyster, 2002, p. 574) stated that uptake is the response given by learners after feedback which can be in the form of repair or needsrepair. Repair refers to the uptake which contains correct response, while needs-repair refers to the uptake which still contains errors. The definition of uptake in this study will follow previous studies' definition of uptake. This study will define uptake as participants' immediate response to the recasts given.

Learners' perceptions of recasts are believed to play a significant role to their ability in giving uptake. One of the studies examining the relationship between learners' perceptions of recasts and uptake was conducted by Egi (2010). This study examined the relationship between learners' perceptions of recasts and uptake as well as the relationship between learners' perceptions of recasts and modified output. The participants of this study, students who were studying Japanese as a foreign language, were involved in a group task activity and a stimulated recall session. Egi (2010, p. 11) stated that learners produce uptake when they perceive recasts as feedback; however, they are less likely to give uptake when they do not perceive recasts given as feedback. Moreover, in relation to modified output, Egi (2010, p. 13) explained that learners tend to give modified output when they perceive recasts as feedback and be aware of the mismatch between their interlanguage and their L2. The findings showed that there is a high correlation between learners' perceptions of recasts and uptake, as well as modified output.

Another study focusing on corrective feedback and uptake was conducted by Panova and Lyster (2002). This study investigated the relationship between types of corrective feedback and learners' uptake. This study analyzed seven types of corrective feedback which were recasts, translation, clarification request, metalinguistic feedback, elicitation, explicit correction and repetition. The result showed that recasts were the most frequently used type of feedback amongst the seven corrective feedback analyzed. However, the percentage of uptake produced by learners after recasts was low. According to Panova and Lyster (2002, p. 589), the negative evidence contained in recasts might be correctly perceived only by learners with high proficiency level. In addition, Mackey and Philip (1998, in Panova \& Lyster, 2002, p. 589) also stated that learners with high proficiency level are able to draw inference from the negative evidence provided in recasts; however, learners with low proficiency level may not be aware of this. That is why recasts are less likely to be successful in promoting uptake.

Recasts' failure in promoting uptake is also examined in another study. Lyster and Ranta (1997), in Nicholas, Lightbown \& Spada (2001, p. 739) stated that recasts are the type of corrective feedback that are most unlikely to promote uptake. This might be because learners are not aware of the error correction contained in recasts. As stated by Slimani (1992), in Nicholas, Lightbown \& Spada (2001, p. 739), recasts are one of the types of corrective feedback which usually go unnoticed by learners. This is mostly experienced by low proficiency learners since they do not have sufficient ability to notice the correction contained in recasts. As stated by Panova and Lyster (2000, in Rassaei, 2014, p. 427), recasts might not be advantageous for learners with low proficiency level because they fail to get the corrective focus contained in recasts. This shows that learners, most of whom are low proficiency learners, tend not to give uptake towards recasts because they are not aware of the corrective element contained in recasts.

To sum up, previous studies showed that recasts are effective for L2 development since they contain positive evidence. However, the implicitness of recasts often leads learners

\footnotetext{
*Author(s) Correspondence:

E-mail: theresia.arianti@stkipmnc.ac.id,dery.rovino@stkipmnc.ac.id
} 
to perceive them as confirmation of meaning rather than feedback. This then causes them not to give uptake after the recasts are given (Lyster \& Ranta, 1997; Swain \& Lapkin, 1998).

By considering the results of previous studies conducted by Egi (2010), Lyster (1998a, in Nicholas, Ligtbown \& Spada, 2001) and Panova and Lyster (2000, in Rassaei, 2014), which have been discussed in Review of Literature section, it is hypothesized that participants tend to produce needs-repair uptakes after receiving recasts.

\section{Target Forms}

The linguistic structures chosen for this study are regular and irregular verbs in past tense form. This linguistic form is chosen because Indonesian language does not have past tense; therefore, past tense is considered as problematic for most of Indonesian learners of English. As stated by Ihsan (1989, p. v), Indonesian learners of English often make a tense shift between present tense and past tense. This tense shift is likely to lead to misunderstanding in communication especially when there is no adverb of time provided in the utterance.

\section{RESEARCH DESIGN AND METHODOLOGY}

\section{Participants}

The participants involved in this study are 5 Indonesian learners of English, aged 18, who are in their first semester at $\mathrm{MNC}$ College, English Education study program. All of them have Indonesian language as their L1, with the average length of previous English study for approximately 12 years. All of them study English as a foreign language. These participants are chosen since they have the sufficient amount of English knowledge. Therefore, it is less likely that they are unable to do the jigsaw task used in the procedure. However, the participants' levels of proficiency are quite low, so it is expected that they will produce some mistakes during the task which will enable the examiner to give the recasts. This study includes only 5 students since it is believed that these participants will most likely produce the sufficient amount of mistakes needed for this study due to their lack of English proficiency.

\section{Examiners}

The examiner is a Non-Native Speaker of English, female, who works as an English lecturer in Indonesia. The examiner is 27 years old, with approximately 4.5 years of teaching EFL classes. The examiner is chosen since she has the adequate amount of EFL teaching experience which will enable her to conduct the jigsaw task commonly used in EFL teaching.

\section{Materials}

The material used in this study slightly follows the one used in previous studies examining Interaction Approach. For the material, the current study uses the kind of jigsaw task used by Swain and Lapkin (1998). Stated in Swain and Lapkin (1998, p. 325), learners in their study were asked to tell a story verbally based on the pictures they get before. A time adverbial is written in the material to indicate the participants to use past tense.

A jigsaw task is chosen since it contains pictures which will facilitate the participants in finding the vocabulary to be used in telling the story. Considering the participants' low levels of English, it is believed that a task with pictures will be suitable for this study.

Perhaps it is worth noting that there will be some abbreviations employed. Students are coded as ' $\mathrm{S}$ '. Researchers who deliver the prompters will be coded as 'I' which stands for Interviewer.

\section{Procedure}

The procedure involved participants to do a jigsaw task. Here, each participant worked in pair with an examiner to complete a story. The participant got three cards (card 1, 3

\footnotetext{
*Author(s) Correspondence:

E-mail: theresia.arianti@stkipmnc.ac.id,dery.rovino@stkipmnc.ac.id
} 
and 5) that contain different pictures. The examiner also held three cards (card 2, 4 and 6) which also contained different pictures. Pictures 1 until 6 were basically a sequence of a short story. The participant then needed to describe what picture 1 was about to the examiner by producing at least two sentences. After that, the examiner continued by describing, in at least two sentences, what picture 2 was about to the participant. They did it until all pictures had been described. The story used in this activity described an event that happened in the past; therefore, the participant was expected to use past tense. During this activity, the examiner gave recasts whenever necessary. The whole part of this activity was recorded for the coding analysis.

\section{Analysis Procedure Recast Episodes}

The first step in the analysis is to transcribe the video of the jigsaw task activity. Any utterances that contain recast episodes and uptake were highlighted. The definition of recast episodes used in this study follows the one proposed by Lyster and Ranta (1997). According to Lyster and Ranta (1997, in Egi, 2010 , p. 8), recast episodes refer to any utterance that contains a learner's error and an examiner's recast.

After being highlighted, the uptake instances were then coded. There were two codes which were "repair" and "needs-repair". Any utterance that showed learners' correct uptake after the recasts was put under "repair" sub-code, while any utterance that did not show learners' correct uptake after recasts was put under "needs-repair" sub-code. The "needs-repair" was then divided into three subcodes which were "acknowledgment", "unmodified", and "modified". "Acknowledgment" refers to any uptake that shows learners' recognition of recasts. Here, learners do not reformulate the problematic form that invites the recast. "Unmodified" refers to any uptake containing learners' unmodified reformulation of the problematic error. Any uptake that contains students' incorrect or partially correct modified problematic form was put under "Modified" sub-code. An additional sub code "no uptake" was used to label any utterance that did not show learners' recognition of recasts. The number of uptake in each code was then be counted.

\section{RESULTS AND DISCUSSION}

\section{Results}

The data for the current study included 20 recasts episodes. From the 20 recast episodes gathered during the data collection process, 3 instances showed that participants did not produce uptake. The other 17 episodes showed that uptake was produced after the recasts were given. From 17 uptake, 4 of them resulted in the correct reformulation of the problematic language feature ("repair"), while the rest of them were categorized as "needsrepair". 8 out of 17 "needs-repair" responses were labelled as "acknowledgement", while the 3 of them were under "unmodified" label. The other 2 episodes were characterized as "modified". The summary of the data is shown in the chart below.

Table 1. Data

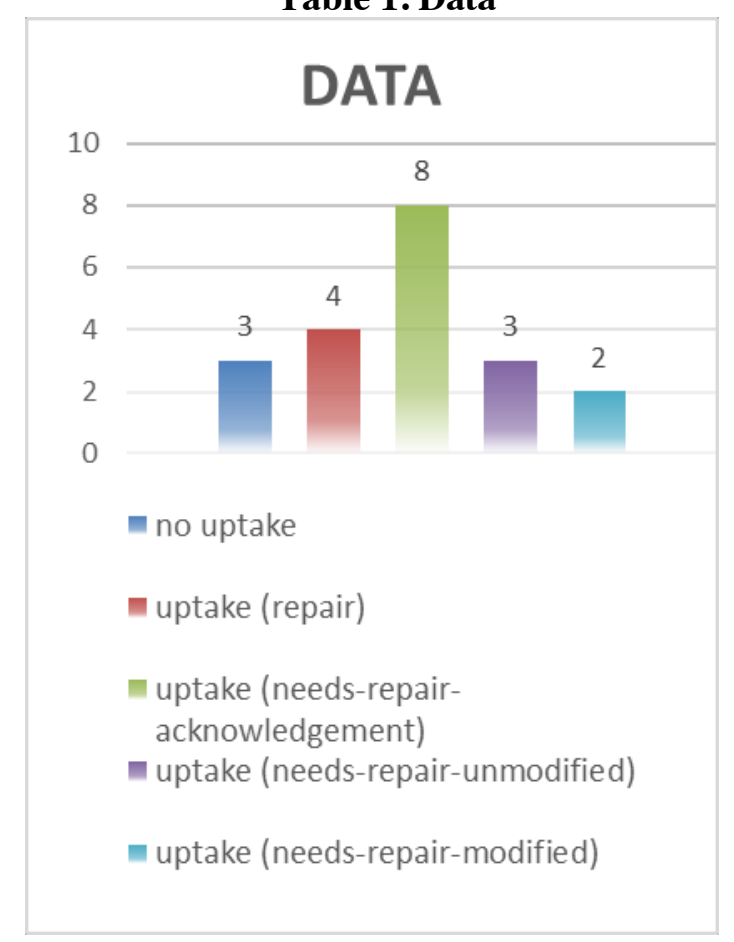

*Author(s) Correspondence:

E-mail: theresia.arianti@stkipmnc.ac.id,dery.rovino@stkipmnc.ac.id 
From the data it can be seen that most of the uptake is categorized as needs-repair (acknowledgement) , while "modified" category has the least number of uptake. These findings contradict the ones found by Egi (2010) which revealed that the type of uptake that was mostly produced by participants during the study was "repair".

\section{Discussion}

\section{- No Uptake}

It was evident that 3 out of 20 recast episodes showed "no uptake" responses, as shown in the excerpts below.

\section{Excerpt 1}

\begin{tabular}{|l|l|}
\hline I: & $\begin{array}{l}\text { Okay... and then, after that (clears } \\
\text { throat) um... suddenly there was a } \\
\text { man came and sat near Joanne and } \\
\text { Joanne looked confused. }\end{array}$ \\
\hline S: & $\begin{array}{l}\text { Okay... the man raise he... the man } \\
\text { that sit next to Joanne } \square \text { error }\end{array}$ \\
\hline I: & $\begin{array}{l}\text { Interrupts) the man that sat next to } \\
\text { Joanne um uhm... } \square \text { recast }\end{array}$ \\
\hline S: & $\begin{array}{l}\text { Recasts went unacknowledged, S } \\
\text { continued to tell the story }\end{array}$ \\
\hline
\end{tabular}

\section{Excerpt 2}

\begin{tabular}{|l|l|}
\hline I: & Uhum? cheer up? \\
\hline S: & Cheer up Jane $\square$ error \\
\hline I: & So the man cheered up Jane $\square$ recast \\
\hline S: & $\begin{array}{l}\text { Recasts went unacknowledged, S } \\
\text { continued to tell the story }\end{array}$ \\
\hline
\end{tabular}

\section{Excerpt 3}

\begin{tabular}{|l|l|}
\hline S: & $\begin{array}{l}\text { run and and bring he... her cap. } \\
\text { uptake and error }\end{array}$ \\
\hline I: & $\begin{array}{l}\text { oh so the mouse ran and brought her } \\
\text { cap } \square \text { recast }\end{array}$ \\
\hline S: & $\begin{array}{l}\text { Recasts went unacknowledged, S } \\
\text { continued to tell the story }\end{array}$ \\
\hline
\end{tabular}

As shown in the excerpts above, participants did not give uptake after the recasts were provided. Participants continued telling the story without trying to reformulate the error having been produced. There seemed to be minimal to the absence of awareness of participants that recasts had been given. It might be due to the participants' low levels of English, especially in terms of vocabulary.

\section{- Uptake (repair)}

4 out of 20 recast instances showed that participants produced the expected corrections of the problematic language features (repair). The data are shown in the excerpt below.

\section{Excerpt 4}

\begin{tabular}{|l|l|}
\hline S: & $\begin{array}{l}\text { She was waiting the bus because the } \\
\text { bus come too late. } \square \text { error }\end{array}$ \\
\hline I: & $\begin{array}{l}\text { Hmm okay so she was waiting for the } \\
\text { bus because the bus came late? } \\
\text { recast }\end{array}$ \\
\hline S: & Yes came late. (confirms) $\square$ uptake \\
\hline
\end{tabular}

\section{Excerpt 5}

\begin{tabular}{|l|l|}
\hline S: & $\begin{array}{l}\text { The mouse in his head is fall down. } \\
\text { error }\end{array}$ \\
\hline I: & So the mouse fell down then $\square$ recast \\
\hline S: & Yes fell down (confirms) $\square$ uptake \\
\hline
\end{tabular}

\section{Excerpt 6}

\begin{tabular}{|l|l|}
\hline S: & $\begin{array}{l}\text { He opened uh... he... he rise his head. } \\
\square \text { error }\end{array}$ \\
\hline I: & uh uhm... (confirms) \\
\hline S: & and then \\
\hline I: & $\begin{array}{l}\text { (interrupts) so he... raised his head. } \\
\text { recast }\end{array}$ \\
\hline S: & $\begin{array}{l}\text { raised his head. yes. In his head } \\
\text { there's... what is this? a squirrel? } \\
\text { uptake }\end{array}$ \\
\hline
\end{tabular}

\section{Excerpt 7}

\begin{tabular}{|l|l|}
\hline S: & $\begin{array}{l}\text { Yesterday... Jon and her dad wait the } \\
\text { bus } \square \text { error }\end{array}$ \\
\hline I: & $\begin{array}{l}\text { Um so yesterday Joanne and her dad } \\
\text { waited } \square \text { recast }\end{array}$ \\
\hline S: & Waited the bus. $\square$ uptake \\
\hline
\end{tabular}

*Author(s) Correspondence:

E-mail: theresia.arianti@stkipmnc.ac.id,dery.rovino@stkipmnc.ac.id 
As shown in the above examples, participants successfully reformulated their errors by producing the expected uptake. Participants were aware that recasts had been given; therefore, they were able to successfully correct their errors. It can also be seen that participants perceived recasts as corrective feedback instead of confirmation of meaning since they finally produced the correct forms of their errors. This might be due to the participants' more adequate levels of English, if compared to other participants who produced the other uptake.

\section{- Uptake (needs repair: acknowledgement)}

8 out of 20 recast instances showed that participants acknowledged the recasts, but were unable to reformulate the errors. The acknowledgement was indicated by some words such as "Yes", "Uhm-hm", and "yeah". The examples are shown in the excerpts below.

\section{Excerpt 8}

\begin{tabular}{|l|l|}
\hline S: & $\begin{array}{l}\text { yeah Joane and her dad meet with a } \\
\text { magician. } \square \text { error }\end{array}$ \\
\hline I: & $\begin{array}{l}\text { Oo okay so Joane and her dad met a } \\
\text { magician. } \square \text { recast }\end{array}$ \\
\hline S: & Yes. (confirms) $\square$ uptake \\
\hline
\end{tabular}

\section{Excerpt 9}

\begin{tabular}{|l|l|}
\hline S: & And she keep laughing. $\square$ error \\
\hline I: & So she kept laughing? $\square$ recast \\
\hline S: & Yes. (confirms) $\square$ uptake \\
\hline
\end{tabular}

\section{Excerpt 10}

\begin{tabular}{|l|l|}
\hline S: & $\begin{array}{l}\text { It's sitting in the chair and the... and } \\
\text { his dad reading a... maybe... } \\
\text { newspaper } \square \text { error }\end{array}$ \\
\hline I: & $\begin{array}{l}\text { um kay... so Joanne and her dad were } \\
\text { waiting and his dad was reading a } \\
\text { newspaper. } \square \text { recast }\end{array}$ \\
\hline S: & yea (confirms) \\
\hline
\end{tabular}

Excerpt 11

\begin{tabular}{|l|l|}
\hline S: & $\begin{array}{l}\text { and then... there have a people come } \\
\text { (unintelligible) } \square \text { error }\end{array}$ \\
\hline I: & $\begin{array}{l}\text { okay so there was someone who came } \\
\text { there ya? } \square \text { recast }\end{array}$ \\
\hline S: & uhm (confirms) \\
\hline
\end{tabular}

\section{Excerpt 12}

\begin{tabular}{|l|l|}
\hline S: & $\begin{array}{l}\text { there's a squirrel inside his head and } \\
\text { then Joan... laughed /lowkh/ } \\
\text { (mispronounciation) at hi... at him } \square \\
\text { error }\end{array}$ \\
\hline I: & Um... there was a squirrel $\square$ recast \\
\hline S: & yes (confirms) $\square$ uptake \\
\hline
\end{tabular}

\section{Excerpt 13}

\begin{tabular}{|l|l|}
\hline S: & $\begin{array}{l}\text { Joanne still laughed /lowkh/ } \\
\text { (mispronounce) } \\
\text { looks confused. } \square \text { error }\end{array}$ \\
\hline I: & $\begin{array}{l}\text { ah so Joanne laughed and his father } \\
\text { looked confused. } \square \text { recast }\end{array}$ \\
\hline S: & yea... $\square$ uptake \\
\hline
\end{tabular}

\section{Excerpt 14}

\begin{tabular}{|l|l|}
\hline S: & $\begin{array}{l}\text { her dad... read (base verb) a } \\
\text { newspaper. } \square \text { error }\end{array}$ \\
\hline I: & $\begin{array}{l}\text { ah... so because her dad read (past } \\
\text { form) a newspaper yeah? } \square \text { recast }\end{array}$ \\
\hline S: & yes (confirms) $\square$ uptake \\
\hline
\end{tabular}

\section{Excerpt 15}

\begin{tabular}{|l|l|}
\hline S: & Yea and Joan is very happy $\square$ error \\
\hline I: & $\begin{array}{l}\text { Oh so Joanne was very happy } \\
\text { recast }\end{array}$ \\
\hline S: & yeah (confirms) \\
\hline
\end{tabular}

As shown above, participants seemed to be aware that recasts were given, indicated by the words "yeah", "yes", and "uhm-hm". However, they did not seem to perceive the recasts as a form of corrective feedback; instead, they simply perceived them as confirmation of meaning. This shows that the implicitness of recasts is likely to yield misperception towards the recasts themselves.

\footnotetext{
*Author(s) Correspondence:

E-mail: theresia.arianti@stkipmnc.ac.id,dery.rovino@stkipmnc.ac.id
} 
- Uptake(needs-repair:unmodified)

3 out of 20 recast episodes showed that participants simply repeated the same problematic language features after the recasts were given. The examples of these episodes are shown below.

\section{Excerpt 16}

\begin{tabular}{|l|l|}
\hline S: & $\begin{array}{l}\text { Yesterday Joane and her dad waiting } \\
\text { bus and then tomorrow Joane and her } \\
\text { dad } \square \text { error }\end{array}$ \\
\hline I: & $\begin{array}{l}\text { Okay so yesterday Joane and her dad } \\
\text { waited for a bus? } \square \text { recast }\end{array}$ \\
\hline S: & $\begin{array}{l}\text { Waiting a bus yes. (confirms) } \\
\text { uptake }\end{array}$ \\
\hline
\end{tabular}

\section{Excerpt 17}

\begin{tabular}{|l|l|}
\hline S: & $\begin{array}{l}\text { eh her.. Joane happy Joane feel } \\
\text { happy just Joane feel happy. } \square \text { error }\end{array}$ \\
\hline I: & $\begin{array}{l}\text { Okay so Joane felt happy at that time. } \\
\square \text { recast }\end{array}$ \\
\hline S: & $\begin{array}{l}\text { Yeah yeah yeah feel happy. } \\
\text { (confirms) } \square \text { uptake }\end{array}$ \\
\hline
\end{tabular}

\section{Excerpt 18}

\begin{tabular}{|l|l|}
\hline S: & $\begin{array}{l}\text { A magician feel nervous..feel nervous } \\
\square \text { error }\end{array}$ \\
\hline I: & so the magician felt nervous. $\square$ recast \\
\hline S: & Feel nervous yes. (confirms) $\square$ uptake \\
\hline
\end{tabular}

Shown in the above excerpts, participants simply repeated the same problematic language features after the recasts were given. They might not perceive the recasts as feedback, or they noticed that the recasts given were corrective feedback, but were unable to produce the correct response. As stated by Egi (2010), 57 out of 375 participants in his study showed that they noticed the gap between their errors and the recasts given. However, only 41 out of 57 participants produced "repair" responses. It shows that not every learner who notices the gap between the error and the recast will produce the expected uptake. It is most likely due to the participants' low levels of English.

\section{- Uptake(needs-repair:modified)}

2 out of 20 recast instances showed that the participants modified their errors, but were still unable to produce the target-like uptake. This uptake was still incorrect or only partially correct. The examples are shown below.

\section{Excerpt 19}

\begin{tabular}{|l|l|}
\hline S: & $\begin{array}{l}\text { Joane's father feel looking magician } \\
\text { error }\end{array}$ \\
\hline I: & $\begin{array}{l}\text { so Joane's father looked at the } \\
\text { magician } \square \text { recast }\end{array}$ \\
\hline S: & $\begin{array}{l}\text { Look at the magician yes. (confirms) } \\
\square \text { uptake }\end{array}$ \\
\hline
\end{tabular}

\section{Excerpt 20}

\begin{tabular}{|l|l|}
\hline S: & $\begin{array}{l}\text { because } \ldots \text { um... her... eh... the moss } \\
\text { is... ran... and... } \square \text { error }\end{array}$ \\
\hline I: & oh the mouse ran? $\square$ recast \\
\hline S: & run .... $\square$ uptake \\
\hline
\end{tabular}

As shown above, participants reformulated the errors into other incorrect words or partially correct words. This shows that they perceived recasts as corrective feedback; however, they did not have sufficient knowledge regarding the correct target forms, which resulted into other incorrect words. This shows that the nature of recasts which does not contain explicit positive evidence has hindered the participants to produce the correct form.

\section{CONCLUSION}

This study was conducted with the aim of investigating which types of uptake the students would produce after recasts were given. The result of the study reveals that "needs-repair: acknowledgement" type of uptake is the one that is mostly produced by learners, which is in line with the hypothesis

\footnotetext{
*Author(s) Correspondence:

E-mail: theresia.arianti@stkipmnc.ac.id,dery.rovino@stkipmnc.ac.id
} 
of the current study. It shows that recasts have not been proven to be effective in eliciting students' correct reformulation of their errors. Looking at it from the lens of students' level of English competence coined with the recast treatments, this study seemed to reveal that recast method might benefit students with a certain level of English structure awareness, specifically that in the past forms.

It is hoped that this study could encourage further studies to discover the reason behind this ineffectiveness of recasts since this has not been examined in the current study, which seems to be the limitation of the current study. It is also hoped that further studies could suggest what adjustments teachers should give to the recasts used in class in order to make them less implicit, for the purpose of making students more aware of the corrective feedback contained in the recasts.

\section{REFERENCES}

BWC extras. (2012). Ghosts [Image]. Retrieved from https://bwcdigital.files.wordpress.com/ 2012/03/wl-0082.jpg

Carpenter, H., Jeon, K. S., MacGregor, D., \& Mackey, A. (2006). Learners' interpretations of recasts. Studies in Second Language Acquisition, 28(2), 209-236.

Easy pace learning. (2017). Supermarket and Groceries Vocabulary [Image]. Retrieved from https://www.easypacelearning.com/des ign/images/Supermarketvocabulary2.j pg

Egi, T. (2010). Uptake, modified output, and learner perceptions of recasts: Learner responses as language awareness. The Modern Language Journal, 94(1), 121.
Haryanto, E. (2015). Teachers' corrective feedback on students' pronunciation at the daffodils english course kampung inggris pare indonesia. Linguists: Journal of Linguistics and Language Teaching, 2(2).

Ihsan, D. (1989). A linguistic study of tense shifts in Indonesian-English interlanguage autobiographical discourse. Ball State University.

Langit-Dursin, R. (2016). Incidental corrective feedback by classroom teachers and uptake by bilingual elementary students in teacher-learner interactions. Indonesian JELT, 11(1), $47-67$.

Leeman, J. (2003). Recasts and second language development: Beyond negative evidence. Studies in Second Language Acquisition, 25(1), 37-63.

Lightbown, P. M., \& Spada, N. (2013). How languages are learned 4th editionOxford Handbooks for Language Teachers. Oxford university press.

Lyster, R., \& Ranta, L. (1997). Corrective feedback and learner uptake: Negotiation of form in communicative classrooms. Studies in Second Language Acquisition, 19(1), 37-66.

Mackey, A., Gass, S., \& McDonough, K. (2000). How do learners perceive interactional feedback? Studies in Second Language Acquisition, 22(4), 471-497.

Maolida, E. H. (2013). A descriptive study of teacher's oral feedback in an ESL young learner classroom in Indonesia. K@TaLama, 15(2), 117-124.

Nicholas, H., Lightbown, P. M., \& Spada, N. (2001). Recasts as feedback to language learners. Language Learning, 51(4), 719-758.

Panova, I., \& Lyster, R. (2002). Patterns of corrective feedback and uptake in an adult ESL classroom. Tesol Quarterly, 36(4), 573-595.

Rassaei, E. (2014). Scaffolded feedback, recasts, and L2 development: A sociocultural perspective. The Modern Language Journal, 98(1), 417-431.

*Author(s) Correspondence:

E-mail: theresia.arianti@stkipmnc.ac.id,dery.rovino@stkipmnc.ac.id 
Solikhah, I. (2016). Oral Corrective Feedback in Speaking Class of English Department. LINGUA: Journal of Language, Literature and Teaching, 13(1), 87-102.

Swain, M., \& Lapkin, S. (1998). Interaction and second language learning: Two adolescent French immersion students working together. The Modern Language Journal, 82(3), 320-337.

*Author(s) Correspondence:

E-mail: theresia.arianti@stkipmnc.ac.id,dery.rovino@stkipmnc.ac.id 